\title{
Parels en perspectieven
}

\author{
R.P. Zwierstra, P. van der Harst, J.M. Meijer, T. Ettema
}

\section{Inleiding}

Het Congres van de Nederlandse Vereniging voor Medisch Onderwijs (NVMO), dat op 21 en 22 november 2001 te Veldhoven is gehouden, werd afgesloten met een samenvattende voordracht die als titel had: 'Parels en perspectieven'. Hierin werd stilgestaan bij de hoogtepunten van het congres: de plenaire en parallelle hoofdlezingen en enkele opvallende onderwerpen en voordrachten. Bovendien werd vooruitgeblikt op de gebeurtenissen en ontwikkelingen die ons in het medisch onderwijs in het komende jaar te wachten staan. Deze bijdrage is een samenvatting van die voordracht.

\section{Parels}

\section{Trainingen}

Het NVMO-congres 2001 startte met een dagdeel trainingen, waarvoor deelnemers zich konden inschrijven. De belangstelling voor deze trainingen bleek groot. Opvallend is dat de helft van de acht aangeboden trainingen gingen over een of andere vorm van reflectie. Kennelijk wordt hiermee tegemoet gekomen aan een toenemende behoefte.

\section{Lezingen}

Er waren drie plenaire lezingen: aan het begin, halverwege en aan het eind van het congres. De lezing aan het einde was een samenvattende lezing: de parels en perspectieven uit dit artikel. Daarnaast werden vijf parallelle lezingen aangeboden.

Competentieleren was het onderwerp van de eerste plenaire lezing. De Bie (BDF adviesgroep, Maurik) bood inzicht in de achtergronden van de terminologieën beroepsgericht, beroepsbekwaam en beroepsdidactiek. Hij maakte duidelijk dat het gebruik van deze begrippen, die met name in het hoger onderwijs in zwang zijn, ook bij de opleiding geneeskunde wel degelijk aan de orde is.

Het belang van self- en peer assessment in gezondheidszorg- en geneeskundeopleidingen werd op overtuigende wijze door Sluysmans (Open Universiteit) neergezet in een parallelle lezing. Vroegtijdig kritisch nadenken over het eigen gedrag en dat van anderen is een complexe vaardigheid die past in de doelstellingen van de medische opleidingen. Opleiding en begeleiding van studenten (en docenten) op dit gebied is noodzakelijk om het doel, het opleiden van een 'reflective practitioner', te bereiken. Dat docenten hierbij gedwongen worden zichzelf een spiegel voor te houden, is een aangename bijwerking van deze benadering.

In een parallelle lezing gaf Bolhuis (UMC St. Radboud, Nijmegen) inhoud aan de begrippen professioneel leren en handelen. Herkenbare onderwerpen, als informeel leren in de praktijk en bewustwording daarvan, werden aan de hand van sprekende voorbeelden uitgewerkt. Deze bijdrage was een goed voorbeeld van een state-of-the-art-lezing die een groter publiek verdient.

Nadat de laatste jaren de aandacht vooral gericht is geweest op de kwaliteit van de curricula, wordt het nu tijd gestructureerd aandacht te schenken aan de kwaliteit van de docent. Stuyt (UMC St. 
Radboud, Nijmegen) poneerde in een parallelle lezing dat onderwijs en opleiding meer dan voorheen expliciet deel uitmaken van de taak van de arts en daarmee onderdeel dienen te zijn van het loopbaanbeleid. Hij pleitte voor profilering op basis van gevolgde onderwijstrainingen en geleverde onderwijsprestaties, een profilering die al kan beginnen tijdens de specialistenopleiding.

De vernieuwde opleiding aan de Erasmus Universiteit Rotterdam werd door Splinter uit de doeken gedaan. Deze parallelle lezing was zeer informatief en had niet misstaan in een sessie met als thema: 'How we do it', waarin ook andere curricula worden toegelicht.

Als laatste parallelle lezing werd door het Studentbestuursleden Overleg Geneeskunde (SOG), onder leiding van De Doelder en Penders, een forumdiscussie gevoerd onder de titel 'Meester en gezel, op zoek naar verbeteringen in de rol van de klinisch docent'. In de nieuwe vormen van onderwijs dreigt deze rol verloren te gaan. Het forum en de discussianten waren het eens over het belang van die rol. De arts-assistent in opleiding is de eerste 'meester'. De vraag is echter: Hoe leert die nu om docent te zijn en meester te worden? Docentvaardigheden zijn helaas niet als eindterm in het Raamplan opgenomen, waarmee afbreuk wordt gedaan aan een deel van de inhoud van de eed van Hippocrates. Een en ander deed Penders verzuchten: De ideale docent is als sinterklaas, je weet dat hij niet bestaat, maar je blijft er in geloven.

Op de tweede dag van het congres werd de plenaire toplezing gegeven door Weggeman. (TU Eindhoven). 'Hoe gaan we om met (de noodzaak tot) vernieuwing', 'hoe leren we het innoveren te managen' waren zijn thema's. Het spanningsveld tussen innovatie en efficiency werd door hem aan de hand van prachtige voorbeelden geschilderd. Twee elementen zijn het gehoor ongetwijfeld bijgebleven: kijk in je organisatie naar de dynamiek van de trainee, de ster, de productietijger en de verteller. De kunst is om die kwaliteiten in de juiste verhouding in de organisatie aanwezig te hebben. Herkenning is essentieel. Het tweede element was om, bij voortschrijdende specialisatie en verdieping, een blijvende verbondenheid met het basisvak te realiseren. Weggeman bracht zijn boodschappen inhoudelijk goed onderbouwd, goed gestructureerd en vooral met verve. Dat hij daarbij voldoende had aan een overheadprojector geeft aan dat zijn verbale en expressieve kwaliteiten nauwelijks aanvulling behoefden.

\section{Andere voordrachten en posters}

Wat waren de andere parels? Wanneer men de 66 voordrachten en 11 posters beschouwt, valt op dat relatief veel bijdragen vertellen over ervaringen die opgedaan zijn met een reeds eerder beschreven methode of een variatie daarop. Uiteindelijk betrof slechts een beperkt aantal voordrachten resultaten van onderzoek waarin, uitgaande van een vraagstelling, een hypothese met een zorgvuldig voorbereide en uitgevoerde methode was getoetst. Deze observatie is in overeenstemming met de doelstelling van het NVMO-congres: informatie-uitwisseling door de leden over zaken die hen bezighouden.

Binnen de veelheid van bijdragen zijn vier hoofdgroepen te onderscheiden waarin de parels gevonden kunnen worden: bijdragen over het objectiveren van methoden, over kwantitatief onderzoek, bijdragen waarin de aandacht wordt gevestigd op bijzondere onderwerpen en bijdragen met een bijzondere presentatievorm.

In de categorie bijdragen over het objectiveren van methoden waren drie parels te 
onderscheiden. Bij de beoordeling van docenten is het van belang op een betrouwbare en valide wijze een oordeel te kunnen geven over de kwaliteit van de begeleiding die een docent geeft tijdens een klinische stage. Pas dan is het mogelijk gefundeerd feedback te geven op het functioneren van de klinisch begeleider. Wolfhagen (Universiteit Maastricht) is erin geslaagd een dergelijk instrument te ontwikkelen en uit haar uitstekende presentatie bleek dat het tevens een goed toepasbaar instrument is. Toepassing ervan levert een sterkte-zwakteprofiel op dat kan dienen als basis voor feedback aan docenten. Daarmee kan het adagium: 'feedback is the lifeblood of learning' worden ondersteund.

In zekere zin overeenkomstig is de ontwikkeling van een instrument voor de beoordeling van reflectievaardigheden. Boenink (VU medisch centrum, Amsterdam) rapporteerde haar vervolgonderzoek op dit gebied. Het gebruikte meetinstrument bleek zowel valide als betrouwbaar. Opvallend was dat co-assistenten een gemiddelde reflectiescore hadden van 4.6 op een tienpuntsschaal. Deze uitkomst onderstreept de noodzaak van aandacht voor dit aspect in het vervolg van het opleidingscontinuüm.

Een andere toepassing van een objectieve beoordelingsmethode werd gepresenteerd door Vernooy-Dassen (Huisartsopleiding, Nijmegen). Bij gebruik van de eerder gevalideerde MAAS-Globaal-lijst voor het beoordelen van consultvaardigheden bleek dat $80 \%$ van de huisartsen wel in staat was volgens communicatieprotocollen te werken, maar dat deze vaardigheden door een veel lager percentage ook werkelijk werden toegepast. In de discussie daarover werd aangegeven dat het toepassen ook lang niet altijd op z'n plaats is en vooral zinvol is in wat moeilijker situaties. Er lijkt eerder sprake van een genuanceerd toepassen dan van belemmeringen voor de toepassing.

In de categorie kwantitatief onderzoek vallen twee bijdragen op. Een fraai en zorgvuldig opgezet onderzoek met een grote relevantie voor de onderwijspraktijk kwam van Adema (Rijksuniversiteit Groningen), die met haar presentatie de NVMO-paperprijs 2001 in de wacht sleepte. Uit haar onderzoek bij 348 studenten naar de verschillen tussen zelfinstructie en begeleide training bij het aanleren van gespreksvaardigheden bleek dat toepassing van zelfinstructie de begeleidingstijd aanzienlijk kon reduceren met behoud van het leereffect. Adema gaf aan dat bij het aanbieden aan studenten van een van deze trainingsvormen rekening gehouden zou moeten worden met de individuele leerstijlen van de student. Een voordracht die met recht een parel genoemd mag worden.

Vanuit de Medische Faculteit in Leuven (Struyf) werden in een drieluik de resultaten van evaluatief onderzoek naar de waardering van studenten voor het probleemoplossingsgericht klinisch college gepresenteerd. Uit het onderzoek naar deze recent ingevoerde onderwijsvorm bleek dat zowel voor studenten als docenten deze vorm niet alleen aantrekkelijk is, maar tevens bijdraagt tot kennisintegratie in een klinische context.

In de categorie 'aandacht vestigen op bijzondere onderwerpen' waren vier parels te onderscheiden. De instroom van buitenlandse artsen van wie het diploma niet wordt erkend, levert bij alle faculteiten problemen op met betrekking tot de aansluiting op de gebieden taalvaardigheid, communicatie, kennis van de Nederlandse gezondheidszorg (gewoonten) en ethiek. Blokker (VU medisch centrum, Amsterdam) lichtte het door hen toegepaste introductieprogramma toe. $\mathrm{Na}$ het doorlopen van dit programma worden 
de studenten, nadat zij geslaagd zijn voor een aantal kennistoetsen, toegelaten tot de co-assistentschappen. Landelijke aandacht en het streven naar gelijkwaardige programma's zijn wenselijk. De opzet van een dergelijk programma is veelbelovend. Het is evenwel jammer dat er geen gegevens gepresenteerd werden over de resultaten van deze aanpak. Die resultaten werden wel getoond door Essink-Bot (Erasmus Universiteit Rotterdam), die een grote inzet van docenten en studenten in een cursus maatschappelijke gezondheidszorg niet gepaard zag gaan met goede resultaten bij het presenteren van werkopdrachten. Taalvaardigheid in het Nederlands bleek hier een belemmerende factor te zijn.

Met de introductie van eindexamenprofielen en de invoering van het studiehuis in het vwo is de inhoud en de wijze waarop onze aspirant-studenten les krijgen aanzienlijk gewijzigd. Opstelten (Faculteit der Medische Wetenschappen, Groningen) vestigde de aandacht op deze fenomenen en gaf aan dat, bij het samenstellen van inhoud en vorm van het propedeuseprogramma en bij het bepalen van toetsvormen, hiermee terdege rekening gehouden dient te worden.

Hoewel in het Raamplan aangegeven staat dat de arts moet kunnen samenwerken, blijkt dat aan dit aspect slechts zelden expliciet aandacht wordt geschonken. Dit geldt evenzeer voor multiprofessioneel onderwijs, terwijl er toch tijdens de opleiding en vooral erna met andere beroepsgroepen wordt samengewerkt. Dit onderwerp, dat door Ter Heine uitstekend wordt beheerst en gebracht, leende zich uitstekend voor een bredere discussie.

Tot slot, de categorie 'bijzondere presentatievormen'. In het domein van toetsing en beoordeling van professioneel gedrag van studenten kan men zich in vele valkuilen laten vangen. Die valkuilen werden op voortreffelijke wijze belicht door drie zeer betrokkenen: De Boer, Ettema en Volbeda, studenten uit Groningen. Aan de hand van een flink aantal prikkelende stellingen werd de volle zaal belangstellenden uitgedaagd een groen of een rood kaartje op te steken en die keus vervolgens te onderbouwen. Een levendig vervolg op de afsluitende voordracht over het consilium abeundi bij het vorige congres. Niet geheel onvoorspelbaar was de conclusie dat voor een goede beoordeling gedegen training van docenten, bij voorkeur samen met studenten, noodzakelijk is.

Bij de posters werd de NVMO-posterprijs 2001 toegekend aan Van Beukelen van de Faculteit Diergeneeskunde: over het invoeren van gescheiden studiepaden. Een echte parel, vooral omdat andere studierichtingen hun voordeel kunnen doen met de bij diergeneeskunde opgedane ervaringen met differentiatie binnen het curriculum.

\section{Perspectieven}

Bij het beschouwen van perspectieven op het gebied van het medisch onderwijs gaan we uit van drie domeinen: de inhoud, de onderwijskundige vormgeving en de logistiek/organisatie van de curricula.

\section{Inhoud}

Wat de inhoud betreft heeft de herziening van Raamplan 1994 geleid tot een aanpassing van de inhoud en de omvang van de beschrijving van de eindtermen van de artsopleiding. We kunnen met Raamplan 2001 goed uit de voeten. De daarin beschreven inhoud wordt in ieder curriculum verschillend ingevuld. In Groningen bijvoorbeeld zijn er in het nieuwe curriculum plannen voor differentiatie in 'Arbeid, Maatschappij en Gezondheid en Klinische Geneeskunde'. Daarbij wordt gebruik gemaakt van het zesde jaar als schakeljaar 
naar de vervolgopleiding. Bij een zorgvuldig gekozen invulling van dat jaar bestaat de mogelijkheid vrijstelling te krijgen voor de eerste onderdelen van de vervolgopleiding. De verwachting is dat de aansluiting van de basisopleiding op de vervolgopleidingen vloeiender zal gaan verlopen, onder andere door het leggen van structurele contacten tussen de opleiders van beide opleidingen.

\section{Onderwijskundige vormgeving}

Wat de onderwijskundige vormgeving betreft zijn in vrijwel alle curricula de sporen van (patiënt)probleemgeoriënteerd onderwijs terug te vinden, waarbij de student actieve kennisverwerver is. Het perspectief is dat ook in de klinische fase deze elementen duidelijker zichtbaar zullen worden. Voor toetsing wordt in de meeste curricula meer ruimte vrijgemaakt in de planvorming. Eerder was toetsing meer een sluitpost. Te verwachten is dat het portfoliosysteem steeds meer terrein zal winnen. Naast de dynamische (formatieve) aspecten van het toetsen wordt in dit systeem aandacht besteed aan het verleggen van de verantwoordelijkheid voor het toetsen van de docent naar de student.

\section{Organisatie}

In steeds meer faculteiten wordt de organisatie van het onderwijs steeds meer aangepast aan de organisatie van het curriculum: bij een centraal ingericht (disciplineonafhankelijk) curriculum past een centrale organisatie vanuit een onderwijsinstituut. Daarbij kan doelmatiger en doeltreffender worden ingespeeld op de logistieke consequenties van de te ver- wachten stijging van het aantal studenten, een fenomeen dat alle faculteiten zeer bezig houdt. Stroomden er in 1999 nog 1800 eerstejaars studenten in, in 2003 worden dat er 2400 en naar verwachting zal in 2003/2004 de instroom verder opgevoerd worden naar 2900 tot 3200 studenten. De onzekerheid over het inrichten van een negende of tiende faculteit (Enschede en/of Tilburg) bemoeilijkt het maken van plannen hiervoor. In de slotvoordracht van het congres werden deze plannen geassocieerd met beelden van donderwolken en bliksemschichten boven beide steden.

Ten slotte is de herijking van de relatie tussen academische ziekenhuizen en geaffilieerde (stage)ziekenhuizen een belangrijk perspectief. In de komende jaren zal zowel kwantitatief als kwalitatief een groter beroep op deze ziekenhuizen moeten worden gedaan. Dit zal een herverdeling van taken en middelen noodzakelijk maken.

In 2002 wordt het NVMO-congres in Egmond aan Zee gehouden, op 14 en 15 november. Dan wordt ook het 35-jarig jubileum van de NVMO gevierd: een mooi perspectief.

\section{De auteurs:}

Prof. dr. R. P. Zwierstra is directeur Onderwijsinstituut, Faculteit der Medische Wetenschappen, Groningen. P. van der Harst, J.M. Meijer en T. Ettema zijn studenten geneeskunde Faculteit der Medische Wetenschappen, Groningen.

Correspondentieadres:

R.P. Zwierstra, Onderwijsinstituut Faculteit der Medische Wetenschappen, A. Deusinglaan 1, 9713 AV, Groningen, r.p.zwierstra@med.rug.nl. 